\section{Is the paradoxical first trimester drop in insulin requirement due to an increase in C-peptide concentration in pregnant Type I diabetic women?}

\begin{abstract}
Dear Sir,
Paradoxically, although normal pregnancy is associated with a two to four fold increase in pancreatic insulin secretion [1], insulin requirements in women who have Type I (insulin-dependent) diabetes mellitus often decline in the first trimester of pregnancy. When insulin doses are not decreased appropriately, hypoglycaemia occurs. Several investigators have reported rates ranging from $36-71 \%$ of moderate to severe hypoglycaemia in women, with a peak incidence between 10 and 16 weeks of pregnancy [2]. We hypothesised that a cause of hypoglycaemia could be the growth promoting factors of pregnancy influencing the rejuvenation of the pancreatic islets [3]. If this is true, pregnancy could serve as a trigger for pancreatic dormant cells to activate proinsulin production and insulin secretion. To test this hypothesis we studied pregnant Type I diabetic women who had documented non-detectable C-peptide concentration before pregnancy (less than $0.08 \mathrm{nmol} / \mathrm{l}$ or $0.25 \mathrm{ng} / \mathrm{ml} \mathrm{mea-}$ sured by Standard radio immunoassay).

We reported the rise in C-peptide concentration at 10 weeks of gestation in ten consecutive pregnant Type I diabetic women (mean \pm SEM, age $31.2 \pm 1.43$ years, duration of diabetes $21.2 \pm 2.8$ years, prepregnancy weight $63.1 \pm 2.1 \mathrm{~kg}$, height $1.67 \pm 0.03 \mathrm{~m}$, prepregnancy body mass index $22.8 \pm 0.4$ $\mathrm{kg} / \mathrm{m}^{2}$ ) who had a greater than $90 \%$ attendance at the diabetic clinic, had precise records of insulin requirements before pregnancy and kept diaries of their own blood glucose measurements with daily insulin requirements. None of the women had impaired renal function. Two had pregnancy-induced hypertension which was adequately treated with methyldopa $250 \mathrm{mg}$ three times a day. Seven of the women had diabetic retinopathy, four had previous laser therapy, and none had active proliferative retinopathy during pregnancy. One had evidence
\end{abstract}

Corresponding author: S. Ilic, Minimed, Inc. 12744 San Fernando Road Sylmar, Ca 91342 USA of carpal tunnel syndrome during her third trimester; however, it was diagnosed as compression-induced and not diabetic neuropathy. None of the other nine women had any evidence of neuropathy. Three had a previous history of hypothyroidism, however all three were replaced with L-thyroxin and were euthyroid throughout pregnancy. All ten women were Caucasian and nulliparous.

At ten weeks of gestation, we measured $\mathrm{C}$ peptide [The normal range for the radioimmunoassay is $0.299-1.332 \mathrm{nmol} / 1$ or $0.9-4.0 \mathrm{ng} / \mathrm{ml}$ (Diagnostic Product Corporation, Los Angeles, Calif., USA)] only in the fasting state, because withholding insulin and giving a Sustacal Challenge according to the protocol of the Diabetes Control and Complications Trial [4] would have produced such marked elevations of blood glucose that this procedure would have been unethical to perform during pregnancy. Thus, all of our measurements during pregnancy were in the fasting state to assure uniformity of the procedure from patient to patient.

Despite a mean first trimester weight gain of $2.0 \pm 0.3 \mathrm{~kg}$, there was a significant decrease in insulin requirement to a mean of $0.61 \pm 0.04 \mathrm{U} / \mathrm{kg}$ from the pre-pregnancy requirement of $0.72 \pm 0.03 \mathrm{U} / \mathrm{kg}(t=3.51, p=0.0048)$ (Table 1$)$. The decline in the first trimester insulin requirement was concomitant with a rise in C-peptide concentration from a non-detectable concentration before pregnancy to a mean concentration of $0.20 \pm 0.02 \mathrm{nmol} / 1$ or $0.58 \pm 0.05 \mathrm{ng} / \mathrm{ml}$ at 10 weeks of gestation.

Of note, one of nur patients did not have a first trimesterdrop in insulin requirement. Possible reasons that not all Type I diabetic women had a drop in insulin requirement are: firstly, some are obese and their insulin production increase was not sufficient enough to overcome their obesity-induced insulin resistance; secondly, some women respond to pregnancy by a pronounced increase in appetite and thus their food intake overrides the small increase in insulin production; and thirdly, some women increased their sleeping time during the day and decrease their daily life activities which increases the insulin requirement more than the small increase in insulin production.

It is not likely that the rise in $\mathrm{C}$ peptide is due to fetal insulin secreted into the mothers' circulation. The C-peptide does not cross the placenta in either direction. Maternal insulin only crosses into the fetal circulation when IgG antibody binds to the molecule [5]. The fetus does not produce IgG antibody until the first month of postnatal life. To investigate whether 
Table 1. C-peptide concentration and insulin requirement before pregnancy and at 10 weeks of gestation

\begin{tabular}{|c|c|c|c|c|c|}
\hline \multirow{2}{*}{$\begin{array}{l}\text { Subject } \\
\text { ID }\end{array}$} & \multirow{2}{*}{$\begin{array}{l}1^{\text {st }} \text { Trimester } \\
\operatorname{HbA}_{1 \mathrm{c}}(\%)\end{array}$} & \multicolumn{2}{|l|}{ Pre-pregnancy } & \multicolumn{2}{|c|}{10 weeks of gestation } \\
\hline & & $\begin{array}{l}\text { C peptide } \\
\mathrm{nmol} / \mathrm{l}(\mathrm{ng} / \mathrm{ml})\end{array}$ & $\begin{array}{l}\text { Insulin requirement } \\
(\mathrm{U} / \mathrm{kg})\end{array}$ & $\begin{array}{l}\text { C peptide } \\
\mathrm{nmol} / \mathrm{l}(\mathrm{ng} / \mathrm{ml})\end{array}$ & $\begin{array}{l}\text { Insulin requirement } \\
(\mathrm{U} / \mathrm{kg})\end{array}$ \\
\hline 1 & 5.9 & $\leq 0.08(\leq 0.25)^{\mathrm{a}}$ & 0.69 & $0.133(0.4)$ & 0.62 \\
\hline 2 & 4.9 & $\leq 0.08(\leq 0.25)^{\mathrm{a}}$ & 0.79 & $0.167(0.5)$ & 0.60 \\
\hline 3 & 5.2 & $\leq 0.08(\leq 0.25)^{\mathrm{a}}$ & 0.74 & $0.267(0.8)$ & 0.48 \\
\hline 4 & 6.5 & $\leq 0.08(\leq 0.25)^{\mathrm{a}}$ & 0.65 & $0.200(0.6)$ & 0.47 \\
\hline 5 & 4.9 & $\leq 0.08(\leq 0.25)^{\mathrm{a}}$ & 0.72 & $0.133(0.4)$ & 0.80 \\
\hline 8 & 6.6 & $\leq 0.08(\leq 0.25)^{\mathrm{a}}$ & 0.73 & $0.167(0.5)$ & 0.61 \\
\hline 9 & 6.0 & $\leq 0.08(\leq 0.25)^{\mathrm{a}}$ & 0.80 & $0.233(0.7)$ & 0.69 \\
\hline 10 & 4.5 & $\leq 0.08(\leq 0.25)^{\mathrm{a}}$ & 0.58 & $0.167(0.5)$ & 0.45 \\
\hline Mean & 5.54 & $\leq 0.08(\leq 0.25)^{\mathrm{a}}$ & 0.72 & $0.20(0.58)$ & $0.61^{\mathrm{b}}$ \\
\hline SEM & 0.20 & $\bar{N} / \mathrm{A}$ & 0.03 & $0.02(0.05)$ & 0.04 \\
\hline
\end{tabular}

${ }^{a}$ Non-detectable C-peptide concentration measured by commercial RIA

${ }^{\mathrm{b}} t=-3.51, p=0.0048$, when compared with pre-pregnancy

or not the $\mathrm{C}$ peptide was due to cross-reactivity with other pregnancy related hormones, we analysed the same samples using three different antibodies to other amino acid sequences of the C-peptide molecule. All three assay techniques confirmed that $\mathrm{C}$ peptide was present. The lower limit of the assay is $0.02 \mathrm{ng} / \mathrm{ml}$ and is achieved by using an overnight incubation procedure. The intra-assay coefficient of variation $(\mathrm{CV})$ for the assay in the low range is $8 \%$ and the inter-assay variation is $16 \%$.

Thus, while insulin requirements in pregnant women with Type I diabetes usually increase by the second half of pregnancy, many have a documented drop in insulin needs in the first trimester independent of food intake, weight gain, thyroid or renal function. Although numerous researchers have suggested that this drop is secondary to the luteal-placental shift of progesterone production, the switch over from the corpus luteum's $17-\mathrm{OH}$ progesterone to placental-progesterone production is possibly not the definitive answer [6-8]. Other investigators [2] have postulated that the drop in insulin requirement may be the result of food restriction or emesis, or both; gravidarum; overinsulinization of previously poorly controlled diabetes; and siphoning of glucose to the foeto-placental unit.

Our study shows that an increase in C-peptide secretion in all ten women with Type-I diabetes could be a cause of the lower insulin doses in the first trimester reported by other investigators [2]. By the second trimester, our patients' C-peptide production was not sufficient to counter the rising anti-insulin forces of placental hormone concentrations, food intake and weight gain and thus the insulin requirements significantly increased to $0.84 \mathrm{U} / \mathrm{kg}$ which exceeded pre-pregnancy requirements $(t=-3.81, p=0.021)$ despite continued measurable Cpeptide secretion. The observation that pregnancy rejuvenated beta-cell function may lead to greater insights into harnessing the factors causing the beta-cell growth and expanding this new knowledge to the field of beta-cell physiology and transplantation.

Yours faithfully,

S. Ilic, L. Jovanovic, A. O. Wollitzer

\section{References}

1. Catalano PM, Tyzbir ED, Roman NM, Amini SM, Sims EA (1991) Longitudinal changes in insulin release and insulin resistance in nonobese pregnant women. Am J Obstet Gynecol 165: 1667-1672

2. Rosnen BM, Miodovnik M (2000) Medical Complications of Diabetes Mellitus in Pregnancy. Clin Obstet Gynecol 43: 17-31

3. Rilo HL, Carroll PB, Trucco M et al. (1994) Human pancreatic islet isolation from a diabetic non-heart-beating donor. Transplant Proc 26: 598

4. The DCCT Research Group (1987) Effects of Age, Duration and Treatment of Insulin-Dependent Diabetes Mellitus on Residual Beta Cell Function: Observations During Eligibility Testing for Diabetes Control and Complication Trial. J Clin Endocrinol Metab 65: 30-36

5. Jovanovic-Peterson L, Kitzmiller JL, Peterson CM (1992) Randomized trial of human versus animal species insulin in pregnancies complicated by diabetes. Am J Obstet Gynecol 167: $1325-1330$

6. Schneider MA, Davies MC, Honour JW (1993) The timing of placental competence in pregnancy after oocyte donation. Fertil Steril 59: 1059

7. Steel J, Johnstone FD, Hume R, Mao J-H (1994) Insulin requirements during pregnancy in women with type 1 diabetes. Obstet Gynecol 83: 253-258

8. Buchanan TA, Metzger BE, Freinkel N, Bergman RN (1990) Insulin sensitivity and $\beta$-cell responsiveness to glucose during late pregnancy in lean and moderately obese women with normal glucose tolerance or mild gestational diabetes. Am J Obstet Gynecol 162: 1008 